\title{
Trophic interactions in shallow lakes of the Pampa plain (Argentina) and their effects on water transparency during two cold seasons of contrasting fish abundance
}

\author{
Alejandro Sosnovsky ${ }^{1, *}$, Juan José Rosso ${ }^{2}$ and Rolando Quirós ${ }^{3, \dagger}$
}

${ }^{1}$ Grupo de Evaluación y Manejo de Recursos Ícticos, Centro Regional Universitario Bariloche, Universidad Nacional del Comahue, Quintral 1250, R8400FRF San Carlos de Bariloche, Argentina

${ }^{2}$ Centro de Estudios Transdisciplinarios del Agua (CETA), Facultad de Ciencias Veterinarias, Universidad de Buenos Aires. Av. Chorroarín 280, C1427CWO, Buenos Aires, Argentina

3 Área de Sistemas de Producción Acuática, Departamento de Producción Animal, Facultad de Agronomía, Universidad de Buenos Aires. Av. San Martín 4453, C1417DSQ, Buenos Aires, Argentina

* Corresponding author: alejandro.sosnovsky@gmail.com

Received: 18/11/09

Accepted: 10/12/09

\begin{abstract}
Trophic interactions in shallow lakes of the Pampa plain (Argentina) and their effects on water transparency during two cold seasons of contrasting fish abundance

Trophic cascade interactions in shallow lakes have been studied extensively in the north temperate region mainly during the summer period. However, fewer studies have examined these interactions in warmer regions during the winter period. The aim of the present work was to study trophic cascade interactions and their effect on water transparency in small lakes in the Pampean Plain (Argentina) during the cold season. In addition, we examined whether low fish abundance would allow the appearance of key zooplankton genera such as Daphnia. Seven shallow lakes were studied during the autumn-winter period in 2000 and 2001. The dominance of the main primary producers varied between lakes. While five lakes were turbid and dominated by phytoplankton, two lakes were clear and dominated by macrophytes. In the autumn of 2000, fish abundance was reduced from six of these lakes. By the following year, the fish community had recovered naturally. In the phytoplankton dominated lakes, both zooplankton biomass and size were higher during the low fish abundance period. Moreover, large Daphnia were present, contributing to the decrease in algal biomass per unit of nutrients. Thus, Daphnia has the potential to increase water transparency in these lakes. On the other hand, in the vegetated lakes, zooplankton biomass was low and large Daphnia were scarce, probably because of the presence of macroinvertebrate predators. However, water transparency was still high in these ecosystems. From our results, we conclude that trophic interactions probably play a fundamental role in the determination of zooplankton structure and biomass in the small, temperate warm lakes of the Pampean Plain, even during the cold season. Moreover, the effects from fish would reach the lowest levels of the trophic chain, affecting water transparency. However, water transparency might be influenced by other factors as well. Transparency could be naturally elevated in the presence of macrophytes and greatly affected by the hydrology of the region.
\end{abstract}

Key words: Whole-lake studies, hypertrophic small lakes, turbid and clear lakes, Daphnia, Zooplankton.

\section{RESUMEN}

Interacciones tróficas en pequeñas lagunas pampeanas (Argentina) y sus efectos en la transparencia del agua durante dos estaciones frías con contrastantes abundancia de peces

Las interacciones tróficas en cascada han sido ampliamente estudiadas en los lagos someros del hemisferio norte, principalmente durante la temporada estival. Sin embargo, su estudio ha sido menos frecuente en los lagos de regiones más cálidas durante la estación fría del año. El objetivo del presente trabajo fue estudiar las interacciones tróficas en cascada de los peces sobre el zooplancton y su posible efecto sobre la transparencia del agua en pequeñas lagunas de la región pampeana (Argentina) durante la estación fría del año. Además, investigamos si una disminución en la abundancia de los peces permitiría la presencia de géneros zooplanctónicos claves tales como Daphnia. Para ello se estudiaron siete lagunas durante el 
otoño e invierno de los años 2000 y 2001. Dos de estas lagunas lagunas fueron nombradas como "claras” pues estuvieron dominadas por la macrófita. En cambio, las otras cinco lagunas fueron nombradas "turbias" pues estuvieron dominadas por el fitoplancton. La abundancia de peces fue reducida en 6 lagunas durante el otoño de 2000. Sin embargo, al año siguiente la comunidad de peces estuvo naturalmente re establecida. En las lagunas dominadas por el fitoplancton, la biomasa y la talla de zooplancton fueron mayores durante el período correspondiente a la baja abundancia de peces. Durante este período, las Daphnia estuvieron presentes y contribuyeron a disminuir la biomasa de fitoplancton por unidad de nutrientes. Por lo tanto estos organismos tendrían la capacidad de incrementar la transparencia del agua de las lagunas. Por otro lado, la biomasa del zooplancton fue escasa y la abundancia de las Daphnia fue baja en las lagunas dominadas por la macrófita, probablemente por el efecto de la predación de organismos invertebrados. A pesar de esto, la transparencia del agua fue elevada en estos ecosistemas. A partir de nuestros resultados, concluimos que las interacciones tróficas determinarían la estructura y la biomasa del zooplancton en las pequeñas lagunas templado cálidas de la región Pampeana, incluso durante la estación mas fría del año. Este efecto en cascada, alcanzaría el eslabón más bajos de la cadena trófica, afectando entonces la transparencia del agua. Sin embargo, la transparencia del agua estaría también influenciada por otros factores. La misma sería naturalmente elevada en presencia de las macrófitas y además estaría altamente afectada por la hidrología de la región.

Palabras clave: Estudios de lago como un todo, pequeñas lagunas hipertróficas, lagos claros y turbios, Daphnia, Zooplancton.

\section{INTRODUCTION}

Trophic cascade theory predicts that predation from higher trophic levels to lower ones could produce a cascading effect throughout the food web (Carpenter et al., 1985). Therefore, in aquatic ecosystems, a decrease in the biomass of planktivorous fish will increase the biomass of herbivorous zooplankton, leading to a decrease in the biomass of phytoplankton. Additionally, the pioneering work of Hrbácek et al. (1961) and Brooks \& Dodson (1965) indicated that fish could be important driving components of the food web by regulating plankton community structure. It has been known for over two decades that fish predation modifies the size structure of the zooplankton community, favouring smaller individuals (Rudstam et al., 1993).

In the northern temperate region, trophic interactions in shallow lakes have been studied extensively (Jeppesen et al., 1997; Benndorf et al., 2002). Understanding these interactions allowed the manipulation of the trophic chain in lakes to increase the water transparency (Drenner \& Hambright, 1999). This manipulation was combined with nutrient loading reductions to favour the clear water state, which is dominated by macrophytes, over the turbid state, which is dominated by phytoplankton (Jeppesen et al., 2007).
For example, manipulating the trophic chain by stocking a lake with piscivorous fish or by selective removal of planktivorous fish (Perrow et al., 1997) favours the large-bodied Daphnia, which may clear the water by grazing on phytoplankton, thereby allowing the development of submerged macrophytes. Zooplankton-macrophyte interactions have positive feedback mechanisms because the macrophyte can act as a refuge for the large-bodied zooplankton and offer protection from possible predators (Timms \& Moss, 1984; Carpenter \& Lodge, 1986; Lauridsen \& Lodge, 1996; Burks et al., 2002).

However, trophic interactions in warmer regions have been studied less often, and several factors indicate that fish manipulation would not have the same positive effect on the environmental state of a lake (Lazzaro, 1997; Jeppesen et al., 2005). Manipulation of fish populations can be difficult because fish assemblages include a high abundance of small, omnivorous prolific fish (Fernando, 1994; Scasso et al., 2001). Alternatively, macrophytes can be highly colonised by both macroinvertebrate predators (Lombardo, 1997; Arnér et al., 1998) and young and littoral fish (Whiteside, 1988). As a result, the capacity of the macrophyte to act as a refuge for zooplankton can be greatly restricted(Meerhoff et al., 2003; Meerhoff et al., 2006; Iglesias et al., 2007). 
Most studies of trophic interactions have focussed exclusively on the summer period, while little is known about the relative importance of predator control of zooplankton in the cold season. During this season, resource control is usually assumed to be more important than predator control because of lower irradiance and lower food concentrations (Sommer et al., 1986). In addition, fish predation may also be lower during winter than in summer due to lower food intake (Keast, 1968) or reduced abundance of predators because some fish take winter refuge in adjacent streams or wetlands (Jepsen \& Berg, 2002).

The aim of the present work was to study trophic cascade interactions, from fish to phytoplankton, during the cold season in Pampean lakes. Additionally, we examined whether low fish abundance allowed for the appearance of key zooplankton genera such as Daphnia. We studied plankton communities during two autumn-winter periods of contrasting fish abundance in both clear and turbid small lakes and investigated whether these trophic interactions could affect water transparency.

\section{MATERIALS AND METHODS}

\section{Study area}

The Pampean Plain, located in the central region of Argentina $\left(33^{\circ}-39 \mathrm{~S}, 57^{\circ}-66^{\circ} \mathrm{W}\right)$, is the most developed agricultural region in the country. The climate is temperate and warm, and the main hydrological characteristic of the region alternates between periods of flood and drought (Vervoorst 1967). The mean annual temperature ranges from $17^{\circ} \mathrm{C}$ in the north to $14^{\circ} \mathrm{C}$ in the south. The mean temperatures for the hottest (January) and coldest (June or July) months are 6 to $8^{\circ} \mathrm{C}$ above, and 5 to $6{ }^{\circ} \mathrm{C}$ below the annual means, respectively (Hall et al., 1992). The mean annual wind speed is $10 \mathrm{~km} \mathrm{~h}^{-1}$ (Torremorell et al., 2007). The Pampa Plain is considered an extensive wetland, where lakes are the dominant feature (Quirós et al., 2006), and there are an enormous number of very shallow lakes in this region. Pampean lakes are not thermally stratified. They were characterised by Quirós \& Drago (1999) as lakes ranging from a eutrophic to a highly hypertrophic trophic state with highly variable water-residence times, average depth, area and salinity.

A large proportion of Pampean lakes are small in area (<50 ha). However, despite their great abundance, studies of these small lakes are scarce. A characteristic of small Pampean lakes is that they can be totally colonised by macrophytes. In these lakes, small, omnivorous fish (mean adult size: 30-60 mm), such as Cnesterodon decemmaculatus, Jenynsia multidentata, Cheirodon interruptus and Bryconamericus iheringii, are present in large numbers; moreover, large (e.g., Hoplias malabaricus) and medium-sized (Oligosarcus jenynsii ) predators are also common (Rosso, 2006). Conversely, large lakes in the region are mostly dominated by open water planktivorous fish, such as Odontesthes bonariensis and Parapimelodus valenciennis, and large piscivorous fish are extremely scarce (Rosso \& Quirós, 2010).

This study was carried out in seven small lakes located in the Pampa Plain. Intensive rowcrop agriculture is practised in these watersheds. Lakes Vedia 1 ( $\left.34^{\circ} 23^{\prime} 12^{\prime \prime} \mathrm{S}-61^{\circ} 33^{\prime} 19^{\prime \prime} \mathrm{O}\right)$, Vedia $2\left(34^{\circ} 24^{\prime} 41^{\prime \prime} \mathrm{S}-61^{\circ} 33^{\prime} 51^{\prime \prime} \mathrm{O}\right)$ and Vedia 3 $\left(34^{\circ} 20^{\prime} 38^{\prime \prime} \mathrm{S}-61^{\circ} 37^{\prime} 57^{\prime \prime} \mathrm{O}\right)$ are situated in intensively-farmed fields, which have, on average, a fertilisation level of $110 \mathrm{~kg}$ nitrogen $\mathrm{ha}^{-1}$ year $^{-1}$, while nitrogen fertilisation reaches, on average, $30 \mathrm{~kg} \mathrm{ha}^{-1}$ year $^{-1}$ in the drainage basins of Lakes Longinotti ( $34^{\circ} 40^{\prime} 21^{\prime \prime} \mathrm{S}-60^{\circ} 56^{\prime} 38^{\prime \prime} \mathrm{O}$ ), Maggi ( $34^{\circ}$ $40^{\prime} 08^{\prime \prime} \mathrm{S}-60^{\circ} 55^{\prime} 12^{\prime \prime} \mathrm{O}$ ), Higueras ( $34^{\circ} 46^{\prime} 07^{\prime \prime} \mathrm{S}-60^{\circ}$ $\left.46^{\prime} 42^{\prime \prime} \mathrm{O}\right)$ and Capurro (34 54'53" $\left.\mathrm{S}-60^{\circ} 51^{\prime} 16^{\prime \prime} \mathrm{O}\right)$ (Sosnovsky and Quirós, 2005). Consequently, nitrogen levels in Lakes Vedia 1, Vedia 2 and Vedia 3 tend to be higher. The lakes were categorised according to their turbid or clear states and on the presence or absence of macrophytes (Table 1). Lakes Maggi and Higueras were grouped as clear lakes, and Lakes Vedia 1, Vedia 2, Vedia 3, Capurro and Longinotti were classified as turbid. All these lakes, with the exception of Lake Maggi, have input and output streams.

\section{Sampling methods and data analysis}

The Department of Aquatic Production Systems of the Buenos Aires University Faculty of Agron- 
Table 1. Limnological characteristics of the lakes. TN: total nitrogen concentration; TP: total phosphorous concentration; Chl $a$ : Chlorophyll $a$ concentration; Macrophyte: Macrophyte abundance as the percentage of lake surface colonised in Lake Maggi; and PVI in Lake Higueras. Mean and range values are represented. The '- ' represents macrophyte absence. Características limnológicas de las lagunas. TN: concentración de nitrógeno total, TP: concentración de fósforo total, Chl a: concentración de clorofila a, Macrófitas: Abundancia de macrófitas estimada como superficie colonizada en la laguna Maggi y como PVI en la laguna Higueras. Se detallan los valores promedios y el rango. - ausencia de macrófita.

\begin{tabular}{|c|c|c|c|c|c|c|c|c|c|c|c|c|c|}
\hline \multirow[t]{2}{*}{ Lake } & \multirow[t]{2}{*}{$\begin{array}{l}\text { Area } \\
\text { (ha) }\end{array}$} & \multicolumn{2}{|c|}{$\begin{array}{l}\text { Water temperature } \\
\qquad\left({ }^{\circ} \mathrm{C}\right)\end{array}$} & \multicolumn{2}{|c|}{$\begin{array}{c}\text { Mean } \\
\text { depth }(\mathrm{cm})\end{array}$} & \multicolumn{2}{|c|}{$\begin{array}{c}\mathrm{TN} \\
\left(\mathrm{mg} / \mathrm{m}^{3}\right)\end{array}$} & \multicolumn{2}{|c|}{$\begin{array}{c}\mathrm{TP} \\
\left(\mathrm{mg} / \mathrm{m}^{3}\right)\end{array}$} & \multicolumn{2}{|c|}{$\begin{array}{c}\mathrm{Chl} a \\
\left(\mathrm{mg} / \mathrm{m}^{3}\right)\end{array}$} & \multicolumn{2}{|c|}{ Macrophyte } \\
\hline & & 2000 & 2001 & 2000 & 2001 & 2000 & 2001 & 2000 & 2001 & 2000 & 2001 & 2000 & 2001 \\
\hline Vedia 3 & 46.6 & $\begin{array}{c}11.4 \\
(9.8-13.8)\end{array}$ & $\begin{array}{c}15.4 \\
(12.6-16.0)\end{array}$ & $\begin{array}{c}125 \\
(118-132)\end{array}$ & $\begin{array}{c}165 \\
(159-171)\end{array}$ & $\begin{array}{c}12735 \\
(11705-13831)\end{array}$ & $\begin{array}{c}8277 \\
(7866-8753)\end{array}$ & $\begin{array}{c}2749 \\
(1313-4152)\end{array}$ & $\begin{array}{c}1361 \\
(1092-1575)\end{array}$ & $\begin{array}{c}371 \\
(289-507)\end{array}$ & $\begin{array}{c}320 \\
(195-473)\end{array}$ & - & - \\
\hline Vedia 2 & 20.6 & $\begin{array}{c}10.0 \\
(8.5-12.8)\end{array}$ & $\begin{array}{c}14.8 \\
(12.3-16.8)\end{array}$ & $\begin{array}{c}61 \\
(55-73)\end{array}$ & $\begin{array}{c}70 \\
(66-77)\end{array}$ & $\begin{array}{c}4918 \\
(2959-6500)\end{array}$ & $\begin{array}{c}3141 \\
(2676-3581)\end{array}$ & $\begin{array}{c}1572 \\
(968-1883)\end{array}$ & $\begin{array}{c}1327 \\
(1161-1482)\end{array}$ & $\begin{array}{c}45 \\
(27-74)\end{array}$ & $\begin{array}{c}120 \\
(92-146)\end{array}$ & - & - \\
\hline Capurro & 7.6 & $\begin{array}{c}11.0 \\
(9.0-13.8)\end{array}$ & $\begin{array}{c}14.2 \\
(8.9-17.6)\end{array}$ & $\begin{array}{c}63 \\
(61-66)\end{array}$ & $\begin{array}{c}70 \\
(66-75)\end{array}$ & $\begin{array}{c}3211 \\
(2116-4888)\end{array}$ & $\begin{array}{c}1096 \\
(910-1421)\end{array}$ & $\begin{array}{c}1798 \\
(1476-1995)\end{array}$ & $\begin{array}{c}1403 \\
(1226-1559)\end{array}$ & $\begin{array}{c}6 \\
(6-8)\end{array}$ & $\begin{array}{c}18 \\
(2-49)\end{array}$ & - & - \\
\hline Vedia 1 & 23.9 & $\begin{array}{c}10.7 \\
(7.9-14.4)\end{array}$ & $\begin{array}{c}15-4 \\
(13.8-17.2)\end{array}$ & $\begin{array}{c}86 \\
(83-87)\end{array}$ & $\begin{array}{c}71 \\
(46-96)\end{array}$ & $\begin{array}{c}2851 \\
(2368-3747)\end{array}$ & $\begin{array}{c}2354 \\
(1490-3415)\end{array}$ & $\begin{array}{c}1065 \\
(688-1438)\end{array}$ & $\begin{array}{c}1139 \\
(971-1229)\end{array}$ & $\begin{array}{c}76 \\
(46-118)\end{array}$ & $\begin{array}{c}96 \\
(35-182)\end{array}$ & - & - \\
\hline Longinotti & 14.0 & $\begin{array}{c}11.5 \\
(9.3-13.3)\end{array}$ & $\begin{array}{c}14.0 \\
(9.4-17.6)\end{array}$ & $\begin{array}{c}72 \\
(62-85)\end{array}$ & $\begin{array}{c}100 \\
(87-111)\end{array}$ & $\begin{array}{c}1848 \\
(1631-2131)\end{array}$ & $\begin{array}{c}1002 \\
(743-1405)\end{array}$ & $\begin{array}{c}1952 \\
(1439-2504)\end{array}$ & $\begin{array}{c}996 \\
(951-1081)\end{array}$ & $\begin{array}{c}2 \\
(0-4)\end{array}$ & $\begin{array}{c}3 \\
(3-4)\end{array}$ & - & - \\
\hline Higueras & 20.8 & $\begin{array}{c}9.8 \\
(8.2-11.4)\end{array}$ & $\begin{array}{c}14.7 \\
(9.7-17.3)\end{array}$ & $\begin{array}{c}103 \\
(94-118)\end{array}$ & $\begin{array}{c}125 \\
(118-131)\end{array}$ & $\begin{array}{c}1306 \\
(1033-1745)\end{array}$ & $\begin{array}{c}592 \\
(200-1140)\end{array}$ & $\begin{array}{c}959 \\
(637-1163)\end{array}$ & $\begin{array}{c}1054 \\
(967-1173)\end{array}$ & $\begin{array}{c}7 \\
(3-13)\end{array}$ & $\begin{array}{c}3 \\
(2-3)\end{array}$ & $\begin{array}{c}70 \\
(50-81)\end{array}$ & $\begin{array}{c}4 \\
(0-13)\end{array}$ \\
\hline Maggi & 3.2 & $\begin{array}{c}10.1 \\
(9.0-11.8)\end{array}$ & $\begin{array}{c}13.3 \\
(9.8-17.9)\end{array}$ & $\begin{array}{c}68 \\
(62-73)\end{array}$ & $\begin{array}{c}150 \\
(145-153)\end{array}$ & $\begin{array}{c}1337 \\
(976-1986)\end{array}$ & $\begin{array}{c}668 \\
(391-1064)\end{array}$ & $\begin{array}{c}2371 \\
(1918-3208)\end{array}$ & $\begin{array}{c}1779 \\
(1604-1887)\end{array}$ & $\begin{array}{c}2 \\
(0-4)\end{array}$ & $\begin{array}{c}7 \\
(2-16)\end{array}$ & $\begin{array}{c}55 \\
(25-80)\end{array}$ & - \\
\hline All lakes & $\begin{array}{c}19.5 \\
(3.2-46.1)\end{array}$ & $\begin{array}{c}10.6 \\
(9.8-11.5)\end{array}$ & $\begin{array}{c}15.5 \\
(13.3-15.4)\end{array}$ & $\begin{array}{c}83 \\
(61-125)\end{array}$ & $\begin{array}{c}107 \\
(70-165)\end{array}$ & $\begin{array}{c}4029 \\
(1306-12735)\end{array}$ & $\begin{array}{c}2447 \\
(592-8277)\end{array}$ & $\begin{array}{c}1781 \\
(959-2749)\end{array}$ & $\begin{array}{c}1294 \\
(996-1779)\end{array}$ & $\begin{array}{c}73 \\
(2-371)\end{array}$ & $\begin{array}{c}81 \\
(3-320)\end{array}$ & $\begin{array}{c}18 \\
(0-81)\end{array}$ & $\begin{array}{c}1 \\
(0-13)\end{array}$ \\
\hline
\end{tabular}

omy carried out a growth study of $O$. bonariensis in six of these lakes from April 2000 to December 2000. In May 2000, prior to stocking the $O$. bonariensis, fish were removed using Endosulfan at a dosage of 10-20 ml $1000 \mathrm{~m}^{-3}$ $\left(1 \cdot 10^{-5}-2 \cdot 10^{-5} \mu \mathrm{g}\right.$ Endosulfán $\left.1^{-1}\right)$, which is a tolerable concentration for crustaceans and insects (Ernst et al., 1991). Fish abundance was reduced in Lakes Vedia 2, Vedia 1, Capurro, Longinotti, Higueras and Maggi. Dead fish were removed with beach seine nets. We took advantage of this opportunity to compare the plankton community and physical-chemical parameters of the lake water during two contrasting fish abundance periods. The first of these periods was in the autumn-winter of 2000 and extended from the time of fish elimination until the stocking of $O$. bonariensis (period of low fish abundance). The fish community was not manipulated in Lake Vedia 3. The second period was during the autumnwinter of 2001, when the fish community had been naturally re-established in the manipulated lakes (period of high fish abundance). The seven lakes were sampled three times between the end of May and September in both periods.
Fish were sampled with gill nets and a small beach seine net. Big fish were sampled with an experimental gill net consisting of a 100-m length made up of ten panels $(30,42,50,60,70,80,105$, 120,150 , and $170 \mathrm{~mm}$ stretched mesh size) set at night. Small fish were sampled with a beach seine net. The catch per unit effort (CPUE, \# fish net ${ }^{-1}$ night $^{-1}$, \# fish $100 / \mathrm{m}^{2}$ ) was used to estimate fish abundance in the autumn of 2000 and 2001. It was not possible to estimate the abundance of the fish community with the beach seine net in Lakes Capurro and Higueras.

Macrophyte abundance was estimated according to their respective colonisation dynamics. Ceratophyllum demersum covered the entire bottom of Lake Higueras in 2000 and 2001, and its abundance was estimated as a percentage of the volume infested (PVI) in the water column (Canfield et al., 1984). In contrast, a carpet of floating macrophyte (Ricciocarpus sp. and Lemna spp.) was present only at certain times during the study period in Lake Maggi. Their abundance, therefore, was estimated as the percentage of the lake surface colonised by the floating macrophytes. 
Plankton and physical-chemical parameters were sampled at the centre of each lake. Zooplankton samples were collected with vertical tows $(0.15 \mathrm{~m}$ diameter conical net, mesh width $69 \mu \mathrm{m})$ $0.25 \mathrm{~m}$ above the lake bottom to the surface. The depth from which zooplankton samples were collected varied in each lake and on each sample date and was, on average, $1.36 \mathrm{~m}$, ranging from $0.65 \mathrm{~m}$ to $2.44 \mathrm{~m}$. All samples were preserved in $4 \%$ sucrose-formalin. To evaluate the phytoplankton biomass and nutrient concentrations, water samples were collected from $0.4 \mathrm{~m}$ beneath the surface. Depth and water transparency (with a Secchi disc) were measured. However, Secchi disc measurements for Lakes Maggi and Higueras from 2000 were not considered in the analysis because of macrophyte coverage.

Zooplanktonic organisms were divided into two groups, mesozooplankton and microzooplankton. Mesozooplankton (i.e., cladocerans and copepods) were counted and measured under a dissecting microscope in a Bogorov chamber. Copepods included both adults and copepodites. Microzooplankton (i.e., nauplii and rotifers) were counted and measured under a microscope in a Sedgwick-Rafter chamber. At least 100 mesozooplankton individuals and 100 microzooplankton individuals from each survey were measured with micrometric oculars. The zooplankton biomass was calculated as dry weight using length-weight regressions (Bottrell et al., 1976). Phytoplankton biomass was estimated as chlorophyll $a$ concentration (Chl $a$ ). Samples were extracted with a chloroform-methanol solution (Wood, 1985), and Chl $a$ absorbance was measured at $665 \mathrm{~nm}$ using a spectrophotometer with a 10-cm path width (A.P.H.A., 1995). The ratio Chlorophyll $a$ /Total Nitrogen (Chl $a / \mathrm{TN}$ ) was used as an indicator of algal biomass in relation to the limiting nutrient. TN was used as the possible limiting nutrient because of the extremely low TN:TP ratio of the study lakes (Sosnovsky \& Quirós, 2005). The phytoplankton biomass (dry weight, DW) was estimated using a $\mathrm{Chl} a / \mathrm{C}$ ratio of 30 and DW/C ratio of 2.2 (Jeppesen et al., 1994). TP was analysed using persulfate digestion and the ascorbic acid method (A.P.H.A., 1995). TN was estimated as the sum of organic nitrogen and nitrate nitrogen $\left(\mathrm{NO}_{3}^{-}-\mathrm{N}\right)$. Total organic nitrogen was estimated by the Kjeldahl method, and ammonia in the digested samples was determined using an ORION-specific electrode (A.P.H.A., 1995). The concentration of $\mathrm{NO}_{3}^{-}-\mathrm{N}$ was read with an ORION-specific electrode following standard procedures (A.P.H.A., 1995). Water temperature was measured with a multiparameter sonde (YSI 85). Information on the daily air temperature from May to September of both years was supplied by the National Meteorological Service.

The Mann-Whitney $U$ test was employed to detect the differences in plankton community variables and in water transparency within each group of lakes between the two periods. Moreover, a paired $t$-test was employed to detect differences in the average daily air temperature and water depth, water temperature, and nutrient concentrations across the seven lakes between the two periods. In addition, we performed a simple linear regression analysis between Secchi disc and Chl $a$, along with a Pearson correlation between Secchi disc and nutrient concentrations across the seven lakes. In the regression, correlation and paired $t$-test analyses, each data point corresponded to the average value in each lake for each study period. To fulfil statistical requirements in these analyses, Chl $a$, Secchi disc, TN and TP were log-transformed (base 10).

\section{RESULTS}

Inter-annual differences were observed in the study region and in the physical, chemical and biological variables of the study lakes (Table 1). The average daily air temperature was significantly lower in 2000 (mean $=10.1$, range $=3.3$ $18.5)$ compared with 2001 (mean $=11.8$, range $=$ 3.7-22.2) (paired $t$-test, $p=0.002$ ). Similarly, water temperature was comparatively lower in 2000 (paired $t$-test, $p<0.001$ ). Moreover, in 2000, the average depth was lower (paired $t$-test, $p=$ 0.041 ), and the TN concentration (paired $t$-test, $p<0.0001$ ) and TP concentration (paired $t$-test, $p=0.031$ ) were higher (Table 1). The floating macrophytes, Ricciocarpus sp. and Lemna spp., 

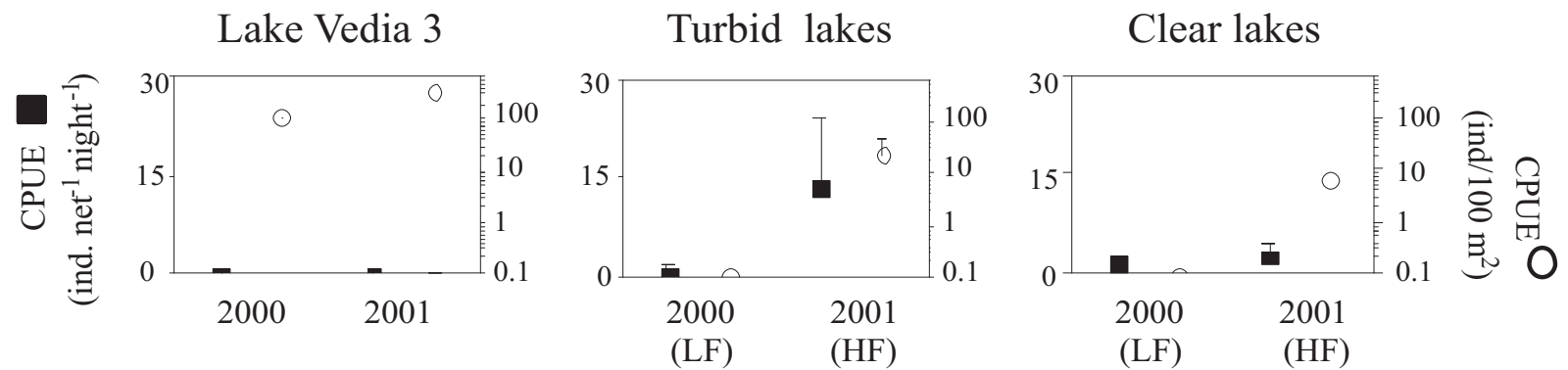

Figure 1. Fish abundance as Catch per Unit of Effort (CPUE) in Lake Vedia 3, the turbid-manipulated lakes and the clearmanipulated lakes; (LF) period of low fish abundance; (HF) period of high fish abundance. Left $\mathrm{Y}$ axis corresponds to the gill net and right $\mathrm{Y}$ axis corresponds to the beach seine net. Values are for mean and standard deviation. Estimación de la abundancia de peces, como Captura por Unidad de Esfuerzo (CPUE) en la laguna Vedia3, las lagunas turbias manipuladas y las lagunas claras manipuladas. (LF) Período con baja abundancia de peces. (HF) Período con elevada abundancia de peces. El eje Y izquierdo corresponde a las capturas obtenidas con la red de enmalle, el eje Y derecho corresponde a las capturas obtenidas con la red de arrastre. Se detallan los valores promedios y el desvio estandar.

were present in Lake Maggi during the 2000 period. In contrast, no macrophytes were present in this lake during the subsequent period (Table 1). Lake Higueras was colonised by $C$. demersum during both study periods; however, the abundance of $C$. demersum was comparatively higher in 2000 (Table 1). Despite the low abundance of macrophytes during 2001, the water transparency remained clear in these two lakes (Fig. 2c).

Inter-annual differences in fish abundance were also observed in the study lakes (Fig. 1). The fish community in Lake Vedia 3 was almost exclusively dominated by small fish. For this reason, the CPUE obtained with the beach seine net was high, whereas that obtained with the gill net was null. Moreover, fish abundance was higher in autumn 2001 than during autumn 2000. As expected, fish abundance was extremely low in 2000 in the manipulated lakes but increased during the subsequent period (Fig. 1). One year after fish elimination, the fish community was once more represented by the organisms characteristic of the Pampean region (Table 2). In 2001, fish abundance was lower in the clear manipulated lakes than in the turbid lakes. However, it should be noted that Lake Maggi was the only lake lacking streams, and fish data were scarce for Lake Higueras.

The plankton community in Lake Vedia 3 exhibited some similarities in the two study periods (Fig. 2a). No differences were observed in biomass or zooplankton abundance. The zooplankton community was dominated by

Table 2. Fish species composition of the lakes in autumn of 2001. Composición de la comunidad de peces de las lagunas en el otoño de 2001.

\begin{tabular}{|c|c|c|c|c|c|c|c|}
\hline & & & & Lakes & & & \\
\hline Fish & Vedia 3 & Vedia 2 & Vedia 1 & Capurro & Longinotti & Higueras & Maggi \\
\hline Jenynsia multidentata & + & + & & + & + & + & + \\
\hline Oligosarcus jenynsii & & + & + & + & + & + & \\
\hline Cheirodon interruptus & + & + & + & + & + & + & \\
\hline Cyphocharax voga & & + & + & + & + & + & \\
\hline Hoplias malabaricus & & + & + & + & + & + & + \\
\hline Corydoras paleatus & & + & + & & + & & \\
\hline Loricariichthys anus & & & & & + & & \\
\hline Odontesthes bonariensis & + & & + & & & & \\
\hline Rhamdia quelen & & + & + & & + & & \\
\hline Australoheros facetus & & + & & & & + & \\
\hline Cyprinus carpio & & + & & & + & & \\
\hline
\end{tabular}


a) Lake Vedia 3

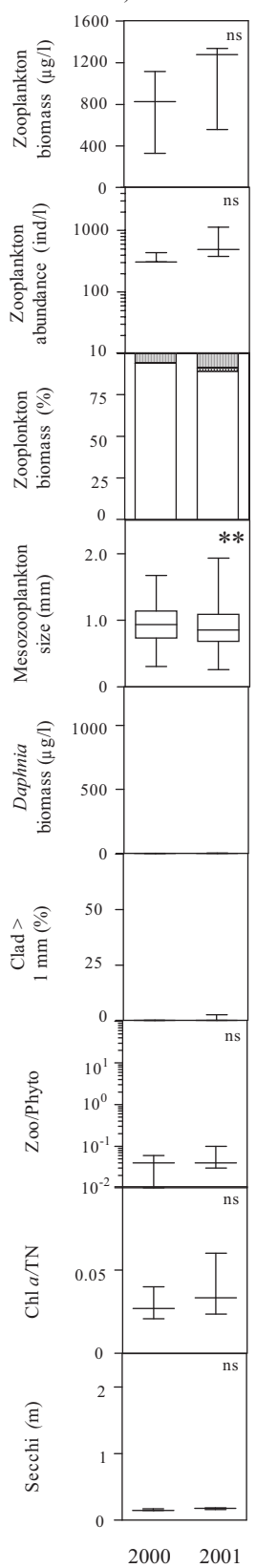

b) Turbid lakes

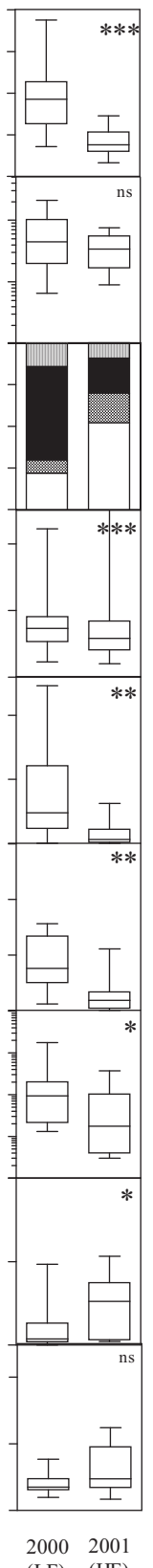

c) Clear lakes

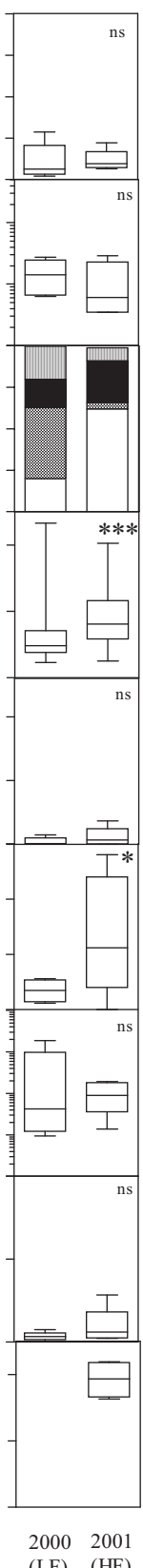

Figure 2. Inter-annual differences in plankton variables and water transparency in Lake Vedia 3, the turbid-manipulated lakes and the clear-manipulated lakes; (LF) period of low fish abundance; (HF) period of high fish abundance. Box plots indicate median and 25-75 percentiles; error bars indicate range. ( $\square$ Copepods, ㅈadocerans other than Daphnia, Daphnia and $\square$ Microzooplankton); Percentage of large cladocerans (Clad > $1 \mathrm{~mm})$; Zooplankton/phytoplankton biomass ratio (Zoo/Phyto); Chlorophyll $a$ per unit of nitrogen $(\mathrm{Chl} a / \mathrm{TN})$. Note that Zoo/Phyto and Zooplankton abundance axes are in $\log$ scale. $* P<0.05 ; * * P<0.01 ; * * * P<$ 0.001; ns, non-significant. Diferencias interanuales en las variables planctónicas y la transparencia del agua en la laguna Vedia 3 , las lagunas turbias manipuladas y las lagunas claras manipuladas. (LF) Período con baja abundancia de peces. (HF) Período con elevada abundancia de peces. Los diagramas de caja indican la mediana y los $25^{\text {avo }}-75^{\text {avo }}$ percentiles, las barras de error indican el rango. ( $\square$ Copépods, $\square$ Cladóceros excepto Daphnia, Daphnia y $\square$ Microzooplancton). Porcentaje de cladóceros mayores a $1 \mathrm{~mm}(\mathrm{Clad}>1 \mathrm{~mm})$. Cociente entre las biomasas de zooplancton y fitoplancton (Zoo/Phyto). Clorofila a por unidad de nitrógeno $(\mathrm{Chl} \mathrm{a} / \mathrm{TN})$. Las escalas correspondientes al eje $Y$ en los gráficos de Zoo/Phyto y Abundancia zooplanctónica son logarítmicas. $* \mathrm{P}<0.05 ; * * \mathrm{P}<0.01 ; * * * \mathrm{P}<0.001 ;$ ns, no significativo. 
copepods; cladocerans were almost absent; and the zooplankton/phytoplankton ratio was low (Fig. 2a). In addition, in accordance with the high Chl $a$ values (Table 1), water transparency was consistently very low in this lake (Fig. 2a). Mesozooplankton size, on the other hand, was significantly greater during the 2000 period, coinciding with the lower fish abundance (Fig. 1). Moreover, despite the comparatively lower water temperature in 2000, Lake Vedia 3 had a greater Chl $a$ value during this period, which is a characteristic not observed in the other turbid lakes (Table 1).

The variation in fish abundance was reflected in the plankton communities of the turbid lakes (Fig. 2b). Zooplankton biomass was relatively higher in the period of low fish abundance; however, no difference in zooplankton abundance was observed between periods. Mesozooplankton size was relatively higher in the period of low fish abundance. Cladocerans, mainly Daphnia, were dominant during this period. This higher Daphnia biomass was reflected in an increase in large cladocerans and an increase in the zooplankton/phytoplankton ratio, which in turn was reflected in a lower $\mathrm{Chl} a / \mathrm{TN}$ ratio. However, water transparency was not significantly higher during the period of low fish abundance.

The effects of the contrasting fish abundance were not reflected in the plankton community of the clear lakes as they were in the turbid lakes (Fig. 2c). No differences were observed in biomass and zooplankton abundance. In addition, despite cladocerans also being the dominant zooplankton group during the period of low fish abundance, Daphnia was not the principle representative (Fig. 2c). Contrary to what was expected, the largest planktonic organisms were observed in the period of relatively high fish abundance, coinciding with the lowest macrophyte coverage (Table 1).

When the entire lake data set was considered as a unit, water transparency was negatively influenced by Chl $a\left(r^{2}=0.48, P=0.013\right)$ (Fig. 3). In addition, a positive relationship was observed between Chl $a$ and TN, (Chl $a$-TN, Pearson correlation $r=0.79, P=0.002)$, whereas a negative correlation was found between this nutrient and water transparency (Secchi disc-TN, Pearson

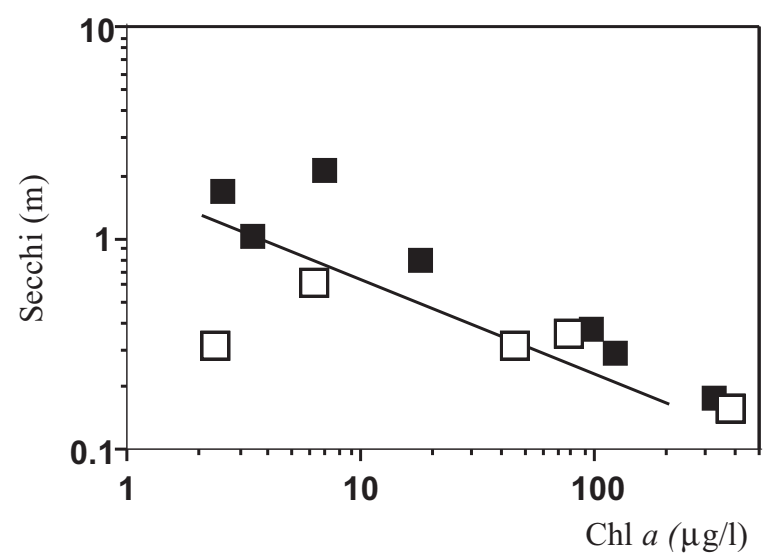

Figure 3. Relationship between chlorophyll a concentration and Secchi disc $\left(r^{2}=0.48, n=12 ; F=9.2, P=0.013\right)$. ( $\square 2000$ 2001) Points correspond to samples taken during the years 2000 and 2001, respectively. Axes are in log scale. Relación entre la concentración de clorofila a y la lectura del disco de Secchi $\left(\mathrm{r}^{2}=0.48, \mathrm{n}=12 ; \mathrm{F}=9.2, \mathrm{P}=0.013\right)$. ( $\square 2000$

- 2001) Los puntos corresponden a muestras obtenidas durante los años 2000 y 2001 respectivamente. Ambos ejes están en escala logarítmica.

correlation $r=-0.92, P<0.0001)$. No significant relationships were observed between TP and Chl $a$ or Secchi disc measurements. It is important to highlight that, in general, all points corresponding to the 2001 study period were positioned above the regression line (Fig. 3).

\section{DISCUSSION}

This study has ecosystem relevance as a Whole lake Study (Carpenter et al., 1995), moreover it is the first study of its kind in the region to be carried out on a set of small lakes. However, future analysis should take into account additional information. For example, in this study, lake selection was imbalanced, with five turbid lakes and only two clear lakes examined in the study. Additionally, a more detailed study on the plankton community requires more than one sample site in each lake. There are various reasons for these failings. On the one hand, compared to the clear lakes, the turbid lakes are more favourable for the growth of $O$. bonariensis, which was the main focus of the original project by the Aquatic Produc- 
tion Systems group. On the other hand, considering that this study was only one part of a more extensive work (Sosnovsky, 2007), the number of samples taken from each lake had to be balanced with the time required for their analysis. However, we believe that the contrasting plankton structure observed in the present work between the two periods is consistent with the direct and indirect effects provoked by the presence or absence of fish in the ecosystem. In addition, this work shows how variations in Pampean hydrology could affect water transparency in these small, shallow lakes, independent of trophic interactions.

Our results suggest that trophic interactions may play a fundamental role in the determination of the structure and biomass of plankton in small Pampean lakes, even during the cold season. Gliwicz (2002) stated that top-down control modifies state variables, such as biomass, individual size and population density. We observed that the decrease in fish biomass was positively reflected in the zooplankton biomass and size in the turbid lakes. The study of zooplankton at the community level may have masked the differences in abundance that were probably present at the population level between the two study periods (e.g., the Daphnia genus). In autumn of 2001, fish abundance increased and fish composition was similar to the original composition (Sosnovsky, personal observation). This observation was probably due to the re-colonisation of fish through neighbouring streams and because the recruitment of those remaining would have been very successful during the next breeding season (Mehner et al., 2002). Accordingly, this increase in fish biomass was negatively reflected in the zooplankton structure in the turbid-manipulated lakes. Thus, these results would agree with other whole-lake studies on eutrophic lakes, which indicated that fish control the zooplankton community during the winter (Rudstam et al., 1993; Jeppesen et al., 2004; Bramm et al., 2009). Moreover, because of the fast recovery of the fish community after a fish kill, only short-term effects on the zooplankton community should be expected (Nagdali \& Gupta, 2002), as observed in our small study lakes.

Zooplankton size and structure are indicators of the intensity of fish predation on the plank- ton community (Brooks \& Dodson, 1965). Mesozooplankton size was significantly higher when fish abundance was relatively lower in the turbidmanipulated lakes. Daphnia is generally an extremely successful competitor in the zooplankton community in fishless lakes. This explains the relatively high Daphnia biomass present in the turbid-manipulated lakes during the low fish abundance period. Moreover, the zooplankton/phytoplankton ratio was higher at this time, possibly indicating a higher zooplankton grazing pressure on the phytoplankton (Jeppesen et al., 1997). This fact was reflected in a lower Chl $a / \mathrm{TN}$ ratio, which is generally associated with increased water transparency. Similar cascade effects through the food web have been observed in the Pampean region (Argentina) and in the subtropical lakes of Uruguay in studies of mesocosms (Boveri \& Quirós, 2007; Iglesias et al., 2008), in lakes (Quirós, 1995; Mazzeo et al., 2000; Rennella \& Quirós, 2002) and whole-lake studies (Sosnovsky \& Quirós, 2009).

The natural fish community in Lake Vedia 3 was very different from other turbid lakes because there was a relatively high abundance of small, omnivorous fish, J. multidentata and C. interruptus, and a total absence of $H$. malabaricus. In contrast, the fish community in the other turbid lakes was more heterogeneous, with planktivorous, omnivorous and piscivorous fish present during 2001. These observed differences between the fish communities are also likely to be reflected in the respective plankton communities. On the one hand, the ratio of cladocerans to mesozooplankton was very low in Lake Vedia 3, which is characteristic of environments where there is a high predation pressure of fish on zooplankton (Jackson et al., 2007). On the other hand, the additional presence of piscivorous fish tends to reduce fish planktivory on zooplankton in the pelagic region of shallow lakes (Wetzel, 2001). This could explain the relatively higher proportion of cladocerans in general, and of Daphnia in particular, observed in the zooplankton communities of Lakes Vedia 1, Vedia 2, Longinotti and Capurro.

The zooplankton biomass and Daphnia biomass were low in the clear lakes, despite low 
fish abundance. This could partly be explained by the predation pressure exercised on the zooplankton by the invertebrates associated with the macrophytes in these two lakes (Sosnovsky personal observation). The elimination of a high percentage of fish leaves the planktivore niche unfilled. This may have permitted invertebrate organisms to invade and occupy this niche (Benndorf et al., 2000; Wissel et al., 2000). This compensatory effect has been documented by various authors in the past (Wissel and Benndorf, 1998; Pinto-Coelho et al., 2008). Recent enclosure experiments support the idea that macrophytes host predatious macroinvertebrates, converting plants into areas of risk for zooplankton in Pampean lakes (González Sagrario et al., 2009) and in the subtropical lakes of Uruguay (Meerhoff et al., 2007). However, low food quality and detrimental physical-chemical conditions, such as low oxygen concentration, could have been complementary causes of the low zooplankton biomass within the highly vegetated areas (Meerhoff $e t$ al., 2007; Fontanarosa et al., 2010). During the autumn-winter of 2001, large cladocerans were present in the clear lakes, suggesting less predation pressure on the zooplankton community. This was most noticeable in Lake Maggi, with its characteristically low fish abundance. Likewise, macroinvertebrate abundance would have been low because of the absence of macrophytes (Lake Maggi) or the lower PVI (Lake Higueras) during that period (Sosnovsky personal observation).

Water transparency might also have been influenced by other factors, despite the intrinsic trophic interactions of the study lakes. Suspended solids and phytoplankton biomass would be extremely low both beneath the floating macrophyte cover and within the highly prominent beds of submerged macrophyte in the clear lakes of the Pampean region. Alternatively, the hydrology of this region may also play a role. At the beginning of the autumn of 2000, the hydrology was characterised by an intense period of drought. During periods of drought, the Pampean lakes decrease both in surface area and depth (Gabellone et al., 2001). Consequently, there are increases in nutrient concentrations (Quirós et al., 2002), algal biomass (Izaguirre and Vinocur, 1994) and, because of higher sediment re-suspension, inorganic turbidity also increases (Garibotti et al., 2009). Because of this, the water transparency of small Pampean turbid lakes would naturally be low during drought (Sosnovsky \& Quirós 2006).

In summary, water temperature and food availability do not seem to be limiting factors for the development of zooplankton, even Daphnia, during the cold season in small Pampean lakes. Moreover, fish are likely to be a key factor in the determination of zooplankton structure and biomass in these lakes and would affect even the lowest level of the trophic chain, thereby affecting water transparency. Even so, water transparency is likely to be influenced by other factors, such as the high macrophyte cover in these lakes and the variable hydrology of the region.

\section{ACKNOWLEDGMENTS}

This work is dedicated to Rolando Quirós, who contributed significantly to the development of limnology in Argentina. A. Sosnovsky and J. J. Rosso acknowledge their fellowships granted by CONICET. We thank A. Rennella for his valuable comments on the manuscript; C. A. Petracchi, D. Blanco Bello, C. Faraminian, J. Alesina, D. Cuffre and H. T. von Bernard for their field assistance, and Audrey Urquhart for helping with the English grammar. A. Sosnovsky thanks J. Armengol for his useful comments during the postdoctoral stay at the Ecology Department of Barcelona University, and we thank two reviewers for helping to improve the final version of the manuscript. This work was supported by the Agencia Nacional de Promoción Científica y Técnica grants PMT-PICT 4698 and PMT-SID 0535.

\section{REFERENCES}

A.P.H.A. 1995. Standard methods for examination of water and wastewater. American Public Health Association. Washington DC. 1064 pp.

ARNÉR, M., S. KOIVISTO, J. NORBERG \& N. KAUTSKY. 1998. Trophic interactions in rockpool food webs: regulation of zooplankton and 
phytoplankton by Notonecta and Daphnia. Freshwater Biology, 39: 79-90.

BENNDORF, J., B. WISSEL, A. F. SELL, U. HORNIG, P. RITTER \& W. BÖING. 2000. Food web manipulation by extreme enhancement of piscivory: an invertebrate predator compensates for the effects of planktivorous fish on plankton community. Limnologica, 30: 235-245.

BENNDORF, J., W. BÖING, J. KOOP \& I. NEUBAUER. 2002. Top-down control of phytoplankton: the role of time scale, lake depth and trophic state. Freshwater Biology, 47: 2282-2295.

BOTTRELL, H. H., Z. DUNCAN, E. GRYGIEREK, A. HERZIG, A. HILLBRICHT-ILKOWSKA, H. KURASAWA, P. LARSON \& T. WEGLENSKA. 1976. A review of some problems in zooplankton production studies. Norwegian Journal of Zoology, 24: 419-456.

BOVERI, M. B. \& R. QUIRÓS. 2007. Cascading trophic effects in pampean shallow lakes: results of a mesocosm experiment using two coexisting fish species with different feeding strategies. Hydrobiologia, 584: 215-222.

BRAMM, M. E., K. L. MAJBRITT, L. LIBORIUSSEN, K. RICHARDSON, M. VENTURA \& E. JEPPESEN. 2009. The role of light for fish-zooplankton-phytoplankton interactions during winter in shallow lakes-a climate change perspective. Freshwater Biology, 54: 1093-1109.

BROOKS, J. L. \& S. I. DODSON. 1965. Predation, body size, and composition of plankton. Science, 150: 28-35.

BURKS, R. L., D. M. LODGE, E. JEPPESEN \& T. L. LAURIDSEN. 2002. Diel horizontal migration of zooplankton: costs and benefits of inhabiting the littoral. Freshwater Biology, 47: 343-365.

CANFIELD, D. E. J., J. V. SHIREMAN, D. E. COLLE, W. T. HALLER, C. E. WATKINS \& M. J. MACEINA. 1984. Prediction of chlorophyll $a$ concentrations in Florida lakes: Importance of aquatic macrophytes. Canadian Journal of Fisheries and Aquatic Sciences, 41: 497-501.

CARPENTER, S. R., J. F. KITCHELL \& J. R. HODGSON. 1985. Cascading trophic interactions and lake productivity. Bioscience, 35: 634-639.

CARPENTER, S. R. \& D. M. LODGE. 1986. Effects of submerged macrophytes on ecosystem processes. Aquatic Botany, 26: 341-370.

CARPENTER, S. R., S. W. CHISHOLM, C. J. KREBS, D. E. SCHINDLER \& R. F. WRIGHT. 1995. Ecosystem experiments. Science, 269: 324-327.
DRENNER, R. W. \& K. D. HAMBRIGHT. 1999. Biomanipulation of fish assemblages as a lake restoration technique (Review). Archiv für Hydrobiologie, 146: 129-165.

ERNST, W. R., P. JONAH, K. DOE, G. JULIEN \& P. HENNIGAR. 1991. Toxicity to aquatic organisms of off-target deposition of endosulfan applied by aircraft. Environmental Toxicology and Chemistry, 10: 103-114.

FERNANDO, C. H. 1994. Zooplankton, fish and fisheries in tropical freshwaters. Hydrobiologia, 272: 105-123.

FONTANAROSA, M. S., G. CHAPARRO, P. DE TEZANOS PINTO, P. RODRÍGUEZ \& I. O'FARRELL. 2010. Zooplankton response to shading effects of free-floating plants in shallow warm temperate lakes: a field mesocosm experiment. Hydrobiologia, 646: 231-242.

GABELLONE, N. A., L. C. SOLARI \& M. C. CLAPS. 2001. Planktonic and physico-chemical dynamics of a markedly fluctuating backwater pond associated with a lowland river (Salado River, Buenos Aires, Argentina). Lakes \& Reservoirs: Research and Management, 6: 133-142.

GARIBOTTI, E. J., P. M. CERVELLINI \& M. C. PICCOLO. 2009. Microcrustáceos planctónicos y características limnológicas de dos lagunas pampeanas (Buenos Aires, Argentina). Limnetica, 28:91-104.

GONZÁLEZ SAGRARIO, M. A., E. G. BALSEIRO, R. B. ITUARTE \& E. D. SPIVAK. 2009. Macrophytes as refuge or risky area for zooplankton: a balance set by littoral predacious macroinvertebrates. Freshwater Biology, 54: 1042-1053.

HALL, A. J., C. M. REBELLA, C. M. GHERSA \& J. CULOT. 1992. Field-crops systems of the pampas. In: Field Crop Ecosystems. C. J. Pearson (ed.): 413-450. Elsevier. New York.

HRBÁCEK, J., V. DVORÁKOVÁ, V. KORÍNEK \& L. PROCHAZKOVA. 1961. Demonstration of the effect of the fish stock on the species composition of zooplankton and the intensity of metabolism of the whole plankton association. Verhandlungen der Internationale Vereingung für Theoretische und Angewandte Limnologie, 14: 192-195.

IGLESIAS, C., G. GOYENOLA, N. MAZZEO, M. MEERHOFF, E. RODÓ \& E. JEPPESEN. 2007. Horizontal dynamics of zooplankton in subtropical Lake Blanca (Uruguay) hosting multiple zooplankton predators and aquatic plant refuges. $\mathrm{Hy}$ drobiologia, 584: 179-189. 
IGLESIAS, C., N. MAZZEO, G. GOYENOLA, C. FOSALBA, F. TEIXEIRA DE MELLO, S. GARCÍA \& E. JEPPESEN. 2008. Field and experimental evidence of the effect of Jenynsia multidentata, a small omnivorous-planktivorous fish, and the size distribution of zooplankton in subtropical lakes. Freshwater Biology, 53: 1797-1807.

IZAGUIRRE, I. \& A. VINOCUR. 1994. Typology of shallow lakes of the Salado River basin (Argentina), based on phytoplankton communities. Hydrobiologia, 277: 49-62.

JACKSON, L. J., T. L. LAURIDSEN， M. SØNDERGAARD \& E. JEPPESEN. 2007. A comparison of shallow Danish and Canadian lakes and implications of climate change. Freshwater Biology, 52: $1782-1792$.

JEPPESEN, E., M. SØNDERGAARD, E. KANSTRUP, B. PETERSEN, R. B. HENRIKSEN, M. HAMMERSHØJ, E. MORTENSEN, J. P. JENSEN \& A. HAVE. 1994. Does the impact of nutrients on the biological structure and function of brackish and freshwater lakes differ? Hydrobiologia, 275/276: 15-30.

JEPPESEN, E., J. P. JENSEN, M. SØNDERGAARD, T. L. LAURIDSEN, L. J. PEDERSEN \& L. JENSEN. 1997. Top-down control in freshwater lakes: the role of nutrient state, submerged macrophytes and water depth. Hydrobiologia, 342/343: 151-164.

JEPPESEN, E., J. P. JENSEN, M. SØNDERGAARD, M. FENGER-GRON, K. SANDBY, P. H. MOLLER \& H. U. RASMUSSEN. 2004. Impact of fish predation on cladoceran body weight ditribution and zooplankton grazing in lakes during winter. Freshwater Biology, 49: 432-447.

JEPPESEN, E., M. SØNDERGAARD, N. MAZZEO, M. MEERHOFF, C. C. BRANCO, V. HUSZAR \& F. SCASSO. 2005. Lake restoration and biomanipulation in temperate lakes: relevance for subtropical and tropical lakes. In: Restoration and Management of Tropical Eutrophic Lakes. V. Reddy (ed.): 341-359. Science Publishers Inc. Enfield.

JEPPESEN, E., M. MEERHOFF, B. A. JACOBSEN, R. S. HANSEN, M. SØNDERGAARD, J. P. JENSEN, T. L. LAURIDSEN, N. MAZZEO \& C. W. C. BRANCO. 2007. Restoration of shallow lakes by nutrient control and biomanipulation-the successful strategy varies with lake size and climate. Hydrobiologia, 581: 269-285.

JEPSEN, N. \& S. BERG. 2002. The use of winter refuges by roach tagged with miniature radio transmitters. Hydrobiologia, 483: 167-173.

KEAST, A. 1968. Feeding of some Great Lakes fishes at low temperatures. Journal of the Fisheries Research Board of Canada, 25: 1199-1218.

LAURIDSEN, T. L. \& D. M. LODGE. 1996. Avoidance by Daphnia magna of fish and macrophytes: chemical cues and predator-mediated use of macrophytes habitat. Limnology \& Oceanography, 41: 794-798.

LAZZARO, X. 1997. Do the trophic cascade hypothesis and classical biomanipulation approaches apply to tropical lakes and reservoirs? Verhandlungen der Internationale Vereingung für Theoretische und Angewandte Limnologie, 26: 719-730.

LOMBARDO, P. 1997. Predation by Enallagma nymphs (Odonata, Zygoptera) under different conditions of spatial heterogeneity. Hydrobiologia, 356: 1-9.

MAZZEO, N., G. LACEROT, C. KRUK, J. GORGA, F. SCASSO, R. L, J. CLEMENTE \& J. GARCÍA 2000. Lago Rivera, situación actual y estrategias para su recuperación. Informe final de la República University. 200 pp.

MEERHOFF, M., N. MAZZEO, B. MOSS \& L. RODRÍGUEZ-GALLEGO. 2003. The structuring role of free-floating versus submerged plants in a subtropical shallow lake. Aquatic Ecology, 37: 377391.

MEERHOFF, M., C. FOSALBA, C. BRUZZONE, N. MAZZEO, W. NOORDOVEN \& E. JEPPESEN. 2006. An experimental study of habitat choice by Daphnia: plants signal danger more than refuge in subtropical lakes. Freshwater Biology, 51: 13201330.

MEERHOFF, M., C. IGLESIAS, F. TEIXEIRA DE MELLOS, J. M. CLEMENTE, E. JENSEN, T. L. LAURIDSEN \& E. JEPPESEN. 2007. Effects of habitat complexity on community structure and predator avoidance behaviour of littoral zooplankton in temperate versus subtropical shallow lakes. Freshwater Biology, 52: 1009-1021.

MEHNER, T., J. BENNDORF, P. KASPRZAK \& R. KOSCHEL. 2002. Biomanipulation of lake ecosystems: successful applications and expanding complexity in the underlying science. Freshwater Biology, 47: 2453-2465.

NAGDALI, S. S. \& P. K. GUPTA. 2002. Impact of mass mortality of a mosquito fish, Gambusia affinis on the ecology of a fresh water eutrophic lake 
(Lake Naini Tal, India). Hydrobiologia, 468: 45-52. PERROW, M., M.-L. MEIJER, P. DAWIDOWICZ \& H. COOPS. 1997. Biomanipulation in shallow lakes: state of the art. Hydrobiologia, 342/343: 355-365.

PINTO-COELHO, R. M., J. F. BEZERRA-NETO, F. MIRANDA, T. G. MOTA, R. RESCK, A. M. SANTOS, P. M. MAIA-BARBOSA, N. A. MELLO, M. M. MARQUES, M. O. CAMPOS \& F. A. BARBOSA. 2008. The inverted trophic cascade in tropical plankton communities: Impacts of exotic fish in the Middle Rio Doce lake district, Minas Gerais, Brazil. Brazilian Journal of Biology, 68: 1025-1037.

QUIRÓS, R. 1995. The effect of fish assemblage composition on lake water quality. Lake \& Reservoir Management, 11: 291-298.

QUIRÓS, R. \& E. DRAGO. 1999. The environmental state of Argentinean lakes: an overview. Lakes \& Reservoirs: Research and Management, 4: 55-64.

QUIRÓS, R., J. J. ROSSO, A. RENNELLA, A. SOSNOVSKY \& M. B. BOVERI. 2002. Análisis del estado trófico de las lagunas pampeanas (Argentina). Interciencia, 27: 584-591.

QUIRÓS, R., M. B. BOVERI, C. PETRACCHI, A. M. RENNELLA, J. J. ROSSO, A. SOSNOVSKY \& H. T. VON BERNARD. 2006. The effects of the pampa wetlands agriculturization on shallow lakes eutrophication. In: Eutrofização na América do Sul: Causas, conseqüências e tecnologías de gestão. J. G. Tundisi, Matsumura-Tundisi, T. \& Sidagis Galli, C. (ed.): 1-16. Rede EUTROSUL, PROSUL. São Carlos, Brasil.

RENNELLA, A. M. \& R. QUIRÓS. 2002. Relations between planktivorous fish and zooplankton in two very shallow lakes of the Pampa Plain. Verhandlungen der Internationale Vereingung für Theoretische und Angewandte Limnologie, 28: 887-891.

ROSSO, J. J. 2006. Peces Pamepanos Guía y Ecología. L.O.L.A. Buenos Aires. 224 pp.

ROSSO, J. J. \& R. QUIRÓS. 2010. Patterns in fish species composition and assemblage structure in the upper Salado River lakes, Pampa Plain, Argentina. Neotropical Ictiology, 8: 135-144.

RUDSTAM, L. G., R. C. LATHROP \& S. R. CARPENTER. 1993. The rise and fall of a dominant planktovre: direct and indirect effect on zooplankton. Ecology, 74: 303-319.

SCASSO, F., N. MAZZEO, J. GORGA, C. KRUK, G. LACEROT, J. CLEMENTE, D. FABIÁN \& S. BONILLA. 2001. Limnological Changes of a subtropical shallow hypertrophic lake during its restoration. Two years of whole-lake experiments. Aquatic Conservation: Marine and Freshwater Ecosystems, 11: 31-44.

SOMMER, U., Z. M. GLIWICZ, W. LAMPERT \& A. DUNCAN. 1986. The Plankton Ecology Group model of seasonal succession of planktonic events in fresh waters. Archiv für Hydrobiologie, 106: 433-472.

SOSNOVSKY, A. \& R. QUIRÓS. 2005. Efectos de la intensidad de uso de la tierra en pequeñas lagunas pampeanas (Argentina). In: Tercer Taller Internacional de Eutrofización de Lagos y Embalses. I. Vila Pinto \& Pizarro Konsak, J. (ed.): 197-215. CYTED Red XVII. Santiago de Chile.

SOSNOVSKY, A. \& R. QUIRÓS. 2006. El estado trófico de las pequeñas lagunas pampeanas. Su relación con la hidrología y la intensidad del uso de la tierra. Ecología Austral, 16: 115-124.

SOSNOVSKY, A. 2007. Factores que determinan la estructura del zooplancton en pequeños cuerpos de agua de la región pampeana. Ph.D. Thesis. Buenos Aires University. 193 pp.

SOSNOVSKY, A. \& R. QUIRÓS. 2009. Effects of fish manipulations on plankton community in small hypertrophic lakes from the Pampa Plain (Argentina). Limnologica, 39: 219-229.

TIMMS, R. M. \& B. MOSS. 1984. Prevention of growth of potentially dense phytoplankton populations by zooplankton grazing in the presence of zooplanktivorous fish in a shallow wetland ecosystem. Limnology \& Oceanography, 29: 472-486.

TORREMORELL, A., J. F. BUSTINGORRY, R. U. ESCARAY \& H. E. ZAGARESE. 2007. Seasonal dynamics of a large, shallow lake, laguna Chascomús: The role of light limitation and other physical variables. Limnologica, 37: 100-108.

WETZEL, R. G. 2001. Planktonic communities: zooplankton and their interactions with fish. In: Limnology Lake and River Ecosystems: 395-488. Academic Press. New York. USA.

WHITESIDE, M. C. 1988. 0+ fish as major factors affecting abundance patterns of littoral zooplankton. Verhandlungen der Internationale Vereingung für Theoretische und Angewandte Limnologie, 23: 1710-1714.

WISSEL, B. \& J. BENNDORF. 1998. Contrasting effects of the invertebrate predator Chaoborus obscuripes and planktivorous fish on the plankton communities of a long term biomanipulation experiment. Archiv für Hydrobiologie, 143: 129-146. 
WISSEL, B., K. FREIER, B. MÜLLER, J. KOOP \& J. BENNDORF. 2000. Moderate planktivorous fish biomass stabilizes biomanipulation by suppressing large invertebrate predator of Daphnia. Archiv für
Hydrobiologie, 149: 177-192.

WOOD, L. W. 1985. Chloroform-methanol extraction of chlorophll-a. Canadian Journal of Fisheries and Aquatic Sciences, 42: 38-43. 